WIDER Working Paper 2021/67

COVID-19 and trade facilitation in Southern Africa

Implications for the AfCFTA

Kudzai Mataba $^{1}$ and Faizel Ismail ${ }^{2}$

April 2021

United Nations University World Institute for Development Economics Research 
Abstract: COVID-19 has created a trade crisis in Southern Africa, with a dramatic slowdown in cross-border trade. The crisis, which exposed weaknesses and deficiencies in the trade facilitation regimes, presents an opportunity for the African Continental Free Trade Area (AfCFTA) to address and contribute to greater levels of trade within Africa. This working paper looks at the impact of the border closures in response to the pandemic, and its impact on trade and the movement of goods in and out of the Southern African Development Community (SADC). The border closures in relation to trade facilitation in Southern Africa and the position of the SADC cluster of ministers of trade and transport are also considered. The paper argues that the AfCFTA should take the lead in addressing the long-term problems of weak trade facilitation systems and bring in measures that would advance greater intra-regional cooperation, including institutional responses and hard infrastructure. The paper concludes with policy recommendations.

Key words: COVID-19, cross-border trade, trade facilitation, regional integration, infrastructure

JEL classification: F15, R1

Acknowledgements: This working paper is part of Workstream 6 on Regional Growth and Development within the project Southern Africa-Towards Inclusive Economic Development (SA-TIED), a three-year partnership between UNU-WIDER and the South African government aimed at improving understanding of regional value chains and supporting industrialization in the Southern African Development Community (SADC) region. It is the sixth paper produced by Trade \& Industrial Policy Strategies (TIPS) for the project. TIPS acknowledges UNU-WIDER and the South African Department of Trade, Industry and Competition for their support.

${ }^{1}$ Trade \& Industrial Policy Strategies (TIPS), Pretoria, South Africa, corresponding author: kudziemataba@gmail.com; ${ }^{2}$ Nelson Mandela School of Public Governance, University of Cape Town, South Africa, and Trade \& Industrial Policy Strategies (TIPS), Pretoria, South Africa

This study has been prepared within the UNU-WIDER project Southern Africa-Towards Inclusive Economic Development (SA-TIED).

Copyright (C) UNU-WIDER 2021

UNU-WIDER employs a fair use policy for reasonable reproduction of UNU-WIDER copyrighted content—such as the reproduction of a table or a figure, and/or text not exceeding 400 words-with due acknowledgement of the original source, without requiring explicit permission from the copyright holder.

Information and requests: publications@wider.unu.edu

ISSN 1798-7237 ISBN 978-92-9267-005-4

https://doi.org/10.35188/UNU-WIDER/2021/005-4

Typescript prepared by Gary Smith.

United Nations University World Institute for Development Economics Research provides economic analysis and policy advice with the aim of promoting sustainable and equitable development. The Institute began operations in 1985 in Helsinki, Finland, as the first research and training centre of the United Nations University. Today it is a unique blend of think tank, research institute, and UN agency — providing a range of services from policy advice to governments as well as freely available original research.

The Institute is funded through income from an endowment fund with additional contributions to its work programme from Finland, Sweden, and the United Kingdom as well as earmarked contributions for specific projects from a variety of donors.

Katajanokanlaituri 6 B, 00160 Helsinki, Finland

The views expressed in this paper are those of the author(s), and do not necessarily reflect the views of the Institute or the United Nations University, nor the programme/project donors. 
The African Continental Free Trade Area (AfCFTA), which envisages the creation of a single market, has the potential to bring together 55 countries, more than 1.2 billion people, and more than US $\$ 3.4$ trillion combined gross domestic product (Oulmane et al. 2020). The agreement provides an impetus for boosting intra-Africa trade and foreign direct investment; however, the success of this regional project relies heavily on substantially lowering the cost of doing business on the continent. In addition, maintaining trade flows as far as possible during the COVID-19 pandemic is critical for ensuring access to essential food and health supplies and, more broadly, limiting the negative impacts on jobs and poverty. The temporary suspension of import tariffs on medical products and equipment in response to the pandemic by several African states is commendable, particularly because many African states rely heavily on tariffs as a source of revenue (Chidede 2020). However, non-tariff barriers, such as cargo clearance delays or import procedures, continue to threaten the movement of critical medical supplies and equipment. The trade facilitation crises that have arisen because of the coronavirus pandemic present an opportunity for the AfCFTA to garner commitment towards addressing the deficiencies in the continent's trade facilitation regimes.

This working paper assesses the impact of the health and economic lockdowns on trade facilitation in Southern Africa and its implications for the AfCFTA. The discussion proceeds as follows. The impact on trade facilitation of the border closures in response to the pandemic is briefly discussed (Section 2). The study assesses the effects that complete and partial border closures have had on the free movement of goods in and out of the Southern African Development Community (SADC). In this context, a case study of South Africa is undertaken (Section 3). The impact of border closures on trade facilitation in Southern Africa and the attitude and positions of the SADC cluster of ministers of trade and transport are then briefly outlined (Section 4). The paper proceeds to explore the opportunities for the AfCFTA to advance greater intra- and interregional cooperation, including on building hard infrastructure, such as developing ports (Section 5). Finally, some policy recommendations are made, including the identification of future research questions (Section 6).

The foundational premise of this research is that trade facilitation need not inhibit national industrialization by promoting imports at the risk of domestic industries (Jansen et al. 2014). On the contrary, decreasing the cost of moving goods between states can make primary and intermediate goods cheaper for manufacturers, thereby enhancing integration into global value chains and increasing export volumes by decreasing the cost of production (Jansen et al. 2014). Furthermore, regional implementation of trade facilitation reforms can result in far more significant benefits for regional economic communities (RECs) and their member states, rather than uncoordinated measures applied autonomously by each country (Jansen et al. 2014). A coordinated regional approach can ensure that traders in the same region are not burdened by different customs formalities and cross-border requirements that hinder cross-border trade in the region. Importantly, uniform formalities and procedures conceived and coordinated at the regional level can remove bottlenecks, increase the participation of small and medium-sized enterprises, and enhance the competitiveness of regional value chains, thus deepening regional integration (Tuomisto 2018). 


\section{Trade facilitation impacts of the COVID-19 pandemic}

\subsection{Trade facilitation and regional integration}

Trade facilitation refers to the broad range of measures that serve to streamline and simplify the technical and legal procedures in the trade of goods. It covers the full spectrum of border processes, ranging from the electronic exchange of data about a shipment to the simplification and harmonization of trade documents, and includes the possibility of appeals of administrative decisions by border agencies (Moïsé and Sorescu 2013). The globalized nature of product value chains often means that goods must traverse several borders during varying stages of completion (i.e. as both intermediate and final products). The aim of trade facilitation is to help lower the overall costs of trade ultimately by decreasing the amount of time it takes for goods to travel from one country to the next (Moïsé and Sorescu 2013). Trade facilitation measures have been defined broadly in two dimensions (Portugal-Perez and Wilson 2012). The hard dimension relates to tangible infrastructure such as ports, roads, or telecommunications. The soft dimension relates to institutional aspects such as customs management and the overall business environment in the country.

Over the past 20 years, concerted efforts have been made through bilateral, regional, and multilateral negotiations towards the de-escalation of the costs of tariffs; however, the non-tariff trade costs have increased particularly in Southern Africa (Viljoen 2019). ${ }^{1}$ Within the Southern African region, there are significant non-tariff costs along the entire supply chain 'from production to the delivery of the goods' (Viljoen 2019). These include the costs of inadequate transit and road infrastructure, inefficient border operations, quality control inspections, successive roadblocks, and quantitative restrictions on goods by individual states (Viljoen 2019). These hard and soft infrastructural inadequacies are compounded by weaknesses in economic governance, which enables corruption. Africa's many landlocked states increases the need for efficient trade facilitation:

A fundamental policy direction ... is to go beyond liberalization to the actual creation of trade potential through developing a flawless trade facilitation environment. (African Union 2012)

Regional approaches to trade facilitation-rather than disjointed national reforms-have the potential to deliver greater benefits to individual countries and the regional community. This is because 'co-ordinated cross-border reforms can help create a more consistent and predictable regional trading environment without having diverging administrative procedures and requirements in each member state' (ITC 2017). The benefits of harmonization of regional trade facilitation formalities will broadly include the overall reduction of the cost of doing business, which will in turn stimulate the building of regional value chains and in the long term facilitate intra-regional investment (ITC 2017). African RECs have a significant role to play in coordinating such reforms as they work towards deeper integration; however, the AfCFTA has the capacity and an even more important role in coordinating interregional cooperation across the continent (ITC 2017).

\footnotetext{
${ }^{1}$ In 2013, members of the World Trade Organization (WTO) finalized negotiations of the WTO Trade Facilitation Agreement (TFA), which set multilateral rules that seek to address specific procedural hurdles in order to facilitate trade procedures. The TFA entered into force in 2017, and the agreement presents a significant opportunity for countries to reap the economic benefits from improving the speed and efficiency of border procedures.
} 


\subsection{National border closures and their impact on trade facilitation}

Both partial and complete border closures can have significant negative welfare and poverty impacts. As far as possible, borders need to be kept open for trade purposes. However, during a pandemic, cooperation is necessary for implementing effective containment measures.

As of 20 May 2020, 43 of 54 African countries had closed their land borders to varying extents, according to the Africa Centres for Disease Control and Prevention (Africa CDC 2020). The movement of goods between states has also been heavily constrained due to tighter security and health controls, which have sometimes allowed only the movement of essential goods. This has arisen from the fear that the captains of vessels and trucks could be transmitters of the virus.

The African continent's trade regime is, however, highly dependent on the mobility of goods. This is partly due to the low levels of industrialization on the continent, which result in a heavy reliance on imports for several economies. During the peak of the pandemic, border posts and seaports across the continent were crowded, controls multiplied, and truck queues were longer than usual (Tshuma 2020). Consequently, trade proceeded at a slower pace, in times when agility and efficiency should have been the highest priority to ensure an adequate response to the pandemic. Efficient trade facilitation processes thus emerge as the backbone to support border agencies in reconciling the safeguarding of public health and the undisrupted movement of goods. The World Bank has noted that, although border closures and more stringent border and seaport processes may in the short term provide some immediate reduction in the spread of the disease, in the medium term they may undermine health protection as countries lose access to essential products to fight the pandemic (Sela et al. 2020).

In April 2020, the World Bank issued two policy guidance notes on trade best practices, to be followed during the pandemic to maintain trade flows (Sela et al. 2020). The primary recommendations include the following:

1 The facilitation of access to essential medical goods and supplies by reducing or suspending import tariffs on such goods or exempting them from value-added tax (VAT) payments.

2 Supporting export industries by suspending quantitative restrictions and taxes on exports.

3 Streamlining regulatory and border procedures to facilitate access to medical goods and essential food products related to COVID-19.

According to the WTO, 15 African states had implemented measures to facilitate access to essential medical goods by suspending import tariffs on such goods or reduced export taxes in some critical industries as of 1 June 2020 (WTO n.d.-a).

\section{Trade facilitation at South African ports during the COVID-19 pandemic: a case study}

On 26 March 2020, the South African government closed 35 land border posts in a bid to control the spread of the coronavirus (SARS n.d.). The borders that remained open were intended to facilitate commercial trade. None of the 35 closed borders are major trading ports of entry. In addition, of the country's eight seaports, two were closed exclusively for passenger travel, while commercial activity could continue, albeit at limited capacity. Health and safety protocols such as the sanitizing of all goods arriving from countries deemed to be 'high risk' by the South African 
National Coronavirus Command Council, and workforce reduction measures, were put in place at the seaports that remained open for commercial purposes. Such measures inevitably led to changes in business-as-usual terminal operations, including the scaling down of operations, particularly for non-essential cargo. Furthermore, all automotive and multipurpose terminals at the ports of East London, Saldanha, Port Elizabeth, and Maydon Wharf in Durban were closed. As a result of the culmination of these and other operational measures taken in response to the pandemic, it is estimated that South African ports operated at below 60 per cent capacity during the most stringent lockdown (level 5), which lasted from 26 March 2020 to 30 April 2020 (SARS n.d.).

The South African Revenue Services (SARS) is a key player in the country's trade and customs administration ecosystem. SARS is responsible for the designation of ports of entry that may be used for trade purposes, and the levying of duties and taxes on imported and exported goods. SARS is also the administrator of the customs process. In this respect, it is responsible for the implementation of customs tariffs, trade agreements, and industry incentives (Lowitt 2019). Since the initiation of South Africa's economic lockdown, SARS has put in place a number of measures to ensure the continued and expedited flow of essential goods into the country. The most notable trade-related policy interventions include:

1 importation of critical supplies ${ }^{2}$ in response to the national state of disaster resulting from the COVID-19 pandemic, free of duty and VAT into South Africa;

2 importation of essential goods, ${ }^{3}$ free of VAT into South Africa, under certain conditions;

3 prioritizing the clearance of essential cargo for inspection to avoid any undue disruption of the supply of critical goods; and

4 extensive use of documentary inspections and, when possible, using non-intrusive examination methods in an effort to limit physical inspections to levels that match operational capacity at the time.

In addition to these concessions for the processing of goods into the country, the South African border management authorities required that truck drivers be screened for the coronavirus (South African Government News Agency 2020). This is unlike the situation is some East African countries, where drivers are required to furnish evidence of a negative coronavirus test, which is only valid for up to 14 days (Tshuma 2020). The screening of drivers instead of requiring testing or test results has significantly eased congestion at South African ports of entry.

These interventions have cumulatively offered considerable assistance in reducing the turnaround time at South African ports of entry for the importing of critical and essential goods, as well as easing the financial burden on importers. Minimal delays have been reported at the country's busiest land border, the Beitbridge border post shared with Zimbabwe. However, the situation at South Africa's main trading seaports has been of considerable concern, particularly for the agricultural industry (Tshuma 2020).

As none of the country's eight seaports were closed during the initial lockdown, and goods coming in from high-risk countries had to be sanitized at first, so changes in terminal operations were

\footnotetext{
${ }^{2}$ Critical supplies are specific goods listed by the International Trade Administration Commission that may qualify for both a rebate of duty and an import VAT exemption. The tariff lines of these goods may be found on the SARS website: www.sars.gov.za/AllDocs/LegalDoclib/SecLegis/LAPD-LSec-COVID19-Reg-2020-07a\%20$\% 20 I T A C \% 20$ VAT $\% 20$ Rebate $\% 20412.11 \% 20$ CRITICAL $\% 20$ MEDICAL $\% 20$ SUPPLIES $\% 20$ re $\% 20$ COVID19\%20(Version\%203\%20-\%206\%20May\%202020).pdf.

${ }^{3}$ Essential goods are defined in Annexure B of the Disaster Management Act under Categories of Essential Goods and Services During Lockdown.
} 
necessary. This meant the scaling down of transportation services and operations of non-essential cargo, which included closure of all automotive and multipurpose terminals at the ports of East London, Saldanha, Port Elizabeth, and Maydon Wharf in Durban, with single berths for handling essential break-bulk goods and containers. Under lockdown level 3, which commenced on 1 June, these ports were reopened (SARS n.d.).

Inefficiencies at South African seaports are a well-documented problem within the South African trade facilitation regime (Lowitt 2019). Although these problems have not been caused by the pandemic, they have been exacerbated in many ways. In an effort to limit the risk of contagion, South African ports have been operating at reduced capacity with limited staff (FreshPlaza 2020). This has resulted in significant delays due to container shortages, space constraints, and long truck queues. Vessel delays and disruptions have become a logistical and financial challenge for producers who race against time to export goods such as fresh produce (FreshPlaza 2020). It is estimated that 90 per cent of African trade is conducted through maritime transport, so the delays at South African ports are of regional significance, particularly to landlocked SADC members (PwC 2018).

The Citrus Growers Association of Southern Africa (CGA) was particularly aggrieved by the measures as the industry moved into its peak export season. The CGA reported increased demand for citrus fruit, especially lemons, from the European market, ostensibly a result of disruption to the Spanish season caused by the pandemic (Meintjes 2020). This increased demand motivated farmers to export earlier than in other seasons, but they were met with constraints at the ports. South Africa is the second-largest exporter of citrus fruits in the world, after Spain, with about 85 per cent of its volume shipped in reefer containers. According to the Fresh Produce Exporters Association, 48 per cent of the exports go through the Port of Cape Town as the majority of citrus products are grown in the Western Cape; 34 per cent go through Durban; and the remaining 18 per cent through the Ngqura Container Terminal in Port Elizabeth.

Adding to the logistical issues being faced by all exporters, citrus exporters must also manage the scheduling of inspections of their products for phytosanitary certification. It was reported that inspectors from the Department of Agriculture, Land Reform and Rural Development (DALRRD) were working at minimum capacity in their efforts to reduce exposure and in response to lower import and export levels. Exporters have thus had limited access to inspection officials (Meintjes 2020). Furthermore, outside of the context of the pandemic, it is estimated that it currently takes an average of 228 hours to get the necessary documents and stamps ready for shipping a container with citrus fruits out of South Africa. These time periods have been significantly increased during the lockdown (Gronholt-Pedersen 2020).

The uncertainty surrounding release times from South African ports, but more particularly the challenges in Cape Town, led some shipping companies to bypass the port to maintain their schedules. In some instances, delays as long as 14 days were experienced (Gronholt-Pedersen 2020). Despite the country's move to a lower virus alert level, the port in Cape Town continued with reduced staff and limited night-shift operations. Due to an increase in detected COVID-19 cases in the Western Cape during May 2020, the CGA warned its members that additional rules applied to vessels arriving in South African ports from 1 June (Gronholt-Pedersen 2020). Vessels arriving at South African ports were served first, with the berthing window suspended. Vessel berthing delays as a result of this new operating procedure saw an increase from an average of 8 days to 12 days. The South African National Ports Authority enforced the force majeure clause in its contracts in June to limit its exposure to insurance claims in light of the situation (Truter 2020).

South Africa has embarked on a modernization project of its port infrastructure in a bid to increase the country's competitive advantage as a shipping point. The port in Durban has been selected to 
pilot this transformative project (Chelin and Reva 2020). Among the most significant innovations at this port is the establishment of an e-commerce platform, and a database that connects the port systems, surveillance cameras, sensors, and tracking tools. Drones are also being used for navigation of ships, monitoring, and data gathering (Chelin and Reva 2020). Smart ports are, however, at considerable risk from a cybersecurity perspective. In 2017, Maersk, which is among the world's biggest shipping lines, experienced a cyberattack that resulted in massive disruption to international supply lines and US $\$ 300$ million in damage (Chelin and Reva 2020). As a result, the fully automated Rotterdam port terminal shut down for more than a week. Other recent cyberattacks include the targeting of port servers and systems at the Port of Barcelona, and a series of ransomware attacks on the port of San Diego and Long Beach (Chelin and Reva 2020).

Although South Africa is at the forefront of the automatization trend on the continent, the country ranks only 56th out of 175 on the 2018 Global Cybersecurity Index, which assesses countries on the level of their cybersecurity commitment. Other African countries with busy ports, such as Egypt, Kenya, and Nigeria, rank 23rd, 44th, and 57th, respectively (Chelin and Reva 2020). This indexing is of considerable concern within the context of the expansion of the automatization process.

The situation at South African ports during the economic lockdown serves merely as an example of challenges being faced at ports across the continent.

\section{$4 \quad$ Border-closure case studies in Southern Africa}

The enforced border closures have been implemented at various levels of strictness. At some borders, adjustments have been made to the clearance of commercial traffic, with priority clearance being granted to essential goods such as food and medicine. In most cases, ports are operating with reduced staff, at times resulting in delays (Tshuma 2020).

For example, at the Beira Port in Mozambique, all vessels are required to send all information required by health authorities in advance of their arrival. In Namibia, compliance with selfquarantine requirements is a prerequisite prior to any vessels being given port clearance. The vessels are also medically screened and cleared by all relevant authorities (Tshuma 2020). The customs administration in Zimbabwe has developed a risk-management approach. What this means in practice is that most customs processes are now being conducted on an online platform to reduce direct contact between customs officials and truck drivers (Tshuma 2020). Except in exceptional circumstances, the physical examination of goods is suspended.

In principle, the South African and Zimbabwean governments have expressed their commitment to facilitate interstate cooperation to allow the continued flow of goods between the two countries (Brenton and Chemutai 2020). During the first three months of the national lockdown in both countries, cargo traffic was low, but processing at the border post was efficient. Border authorities on both sides agreed to use pre-clearance processes to reduce congestion at the port of entry (Maromo 2020). Furthermore, drivers are only screened for COVID-19 on arrival and the requirement of mandatory quarantine and testing as demanded by other countries in the region is not necessary (Chiguvare 2020).

As industries in both Zimbabwe and South Africa have begun to open, following the loosening of lockdown restrictions, the situation at the Beitbridge border post has become of growing concern for freight forwarders (Chiguvare 2020). It was reported that, from 4 August 2020 to early September, commercial vehicles crossing between Zimbabwe and South Africa experienced 
protracted delays (WorldAware 2020). The average clearance time had been pegged at 24 hours to allow for the administration of all relevant health protocols, but after practical experience it was extended to 96 hours (WorldAware 2020). The delays have been attributed to screenings for COVID-19, plus further delays linked to travel restrictions in force in both countries and increased police roadblocks on the highways (WorldAware 2020). In August it was reported that the queue to reach the border post in South Africa was $15 \mathrm{~km}$ long (WorldAware 2020). South African media reports have since drawn attention to the growing tensions at the port of entry as cargo truck drivers have continuously reported preferential treatment given to truck operators willing to pay bribes to facilitate transit, with no response from either state (WorldAware 2020). Truck drivers reportedly blocked access to the border crossing on the South African side during the week beginning 27 July to protest delays and bribery allegations, saying that the delays were incurring huge costs due to extra time payment to truckers, failure to honour contractual delivery obligations, and lost merchandise (WorldAware 2020). Compounding this situation is the fact that, from September 2020, the Zimbabwean border authorities have begun to conduct 100 per cent compliance searches amid growing concerns of smuggling and misdeclarations (Muleya 2020). The border authorities are, however, understaffed, resulting in them searching only two or three trucks each day, which is causing major backlogs in incoming traffic (Muleya 2020).

At the Machipanda-Forbes border post, which separates Zimbabwe and Mozambique, customs officials in Mozambique initially reacted to the economic lockdown in Zimbabwe by unduly prohibiting the passage of trucks from Zimbabwe into Mozambique (Tshuma 2020). Although this initial lack of policy clarity only lasted one day, it caused an unnecessary inconvenience to logistics companies operating in the area (The Herald 2020). Trucks were then permitted to move between the two countries freely, with delays caused by the screening of drivers (The Herald 2020).

The situation at the Zimbabwean-Zambian borders, including the Chirundu One Stop Border Post, Livingstone and Kasumbalesa, which is shared with the Democratic Republic of Congo (DRC), has been slightly more complex. At the Livingstone border post, Zambia has imposed a mandatory quarantine requirement for all truck drivers attempting to enter the country (Mwangi 2020). Zambia serves as one of the transit countries between the landlocked DRC and South Africa. Truck drivers travelling from South Africa were being screened on their exit from South Africa and Zimbabwe or Namibia only to reach Zambia and be further detained for mandatory testing (Tshuma 2020). The border post also has inadequate parking bays for trucks carrying inflammable substances, causing a high risk of explosion. At the Chirundu One Stop Border Post, Zambian clearance procedures created severe congestion, resulting in trucks queuing on the Zimbabwe side of the border northbound (Tshuma 2020). On 2 April 2020, the queue was around $9 \mathrm{~km}$ long (Tshuma 2020). Drivers slept in their trucks for an average of two nights with no ablution facilities, which in itself posed a further health risk during the pandemic (Tshuma 2020). The trucks being held in Zambia while in transit may also be carrying goods to fight the pandemic or items for essential services and special projects (Tshuma 2020). Zambian border processes have thus been accused of creating a bottleneck in the movement of transiting cargo in its efforts to protect national health interests (Tshuma 2020).

\subsection{The SADC response}

The SADC has adopted regional guidelines on harmonization and facilitation of cross-border transport operations during the COVID-19 pandemic (SADC 2020). The guidelines aim to facilitate interstate flows of essential goods such as fuel, food, medical equipment and medicines, including medical supplies, personal protection equipment, and agricultural inputs. They further recommended member states simplify and automate trade and transport facilitation processes, introduce or enhance pre-clearance of goods and single-window processing, and accelerate the creation of online applications and platforms for the processing and clearance of imports and 
exports. ${ }^{4}$ Although it is recognized that the benefits of this policy will not lead to immediate relief for all traders, the hope is that these efforts will continue beyond the crisis and stimulate the harmonization and automation of processes across the region.

The AfCFTA process will need to learn from the disruption and lack of coordination at border stops in Southern Africa and seek to facilitate and encourage the harmonization of border operations.

\section{Opportunities for the AfCFTA to address the trade facilitation challenges highlighted by the pandemic}

The case studies demonstrate the need for coordinated border and customs management, not only between neighbouring states but also along major trade corridors such as the South Africa-DRC route. This is because many African ports of entry lack the necessary hard infrastructure to safely accommodate lengthy delays. The pandemic has not been the cause of these infrastructural challenges, but rather has simply highlighted them. The case studies have mainly focused on the transportation of goods within regional groups that have harmonized clearance procedures. Traders attempting to conduct business between regional groups face the compounded challenge of unharmonized clearance procedures.

The AfCFTA needs to build on the progress achieved by the RECs in their efforts towards regional integration. The agreement has the opportunity to foster greater interregional cooperation, taking cognizance of the fact that many trade corridors cross more than one REC, and the multiple and overlapping memberships of up to 89 per cent of African states in these RECs (Erasmus 2018).

The ongoing crisis has highlighted the logistical complexities involved in transporting goods on the continent primarily because of the long distances that must be travelled through several states.

The AfCFTA requires that state parties 'apply international instruments, standards and practices to attain such trade facilitation objectives, particularly in the area of customs co-operation' (Magwape 2018). The agreement emphasizes the need for 'compliance with international instruments, as is provided in the Trade Facilitation Protocol that customs laws and procedures shall be based on internationally accepted instruments and standards, practices and guidelines applicable in the field of customs and trade' (Magwape 2018).

The Trade Facilitation Protocol incorporated within the legal framework of the AfCFTA thus mirrors the WTO's TFA and, in some ways, seeks to strengthen the commitments made in that agreement. Lessons learned from the attempts towards compliance with the TFA can thus serve as points of departure for the strengthening of the continent's trade facilitation regime.

The TFA came into effect in February 2017 and to date 151 of the WTO's 164 members have ratified this agreement, including 37 of 44 African W'TO member states. Egypt was the most recent African country to ratify on 8 April 2020 (Chidede 2018). The agreement offers an opportunity to streamline trade facilitation processes across the continent by providing a framework within which

\footnotetext{
${ }^{4}$ SADC Guidelines on Harmonisation and Facilitation of Cross Border Transport Operations across the Region during the COVID-19 Pandemic SADC/C-EM/1/2020/4 07/04/2020.
} 
states can shape their reform programmes. It furthermore highlights other important issues deserving national policy attention through the obligation fulfilment matrix.

By providing a framework for trade facilitation reforms, compliance with the TFA provides an opportunity for the overall reduction of the cost of doing business on the continent for African states (TFA4Africa 2021). Developing countries in Africa have, however, benefited from 'special and differential treatment' that in turn permits such members to notify provisions that they will only implement after a transition period (Chidede 2018). Therefore, despite the high number of ratifications witnessed on the continent, African states have been conservative in notifying the more onerous categories B and C of the agreement (Chidede 2018).

The AfCFTA reframes the continental integration project by employing a top-down approach to integration, signalling a break away from the bottom-up approach that has historically been in use (Magwape 2018). The bottom-up approach envisaged that individual RECs were at the centre of, and acted as the conveners of, continental integration projects (Magwape 2018). The main downfall of this approach was that integration projects on the continent were carried out in a disjointed manner, an impediment that was further exacerbated by the overlapping membership of many African states to more than one REC (Magwape 2018). Many intercontinental trade facilitation initiatives have been slow to reap meaningful benefits due to this incoherent approach to integration, which resulted in states pursuing different objectives with different timelines. The result of the bottom-up approach to trade facilitation reforms on the continent was a failure to meet universal time-related targets as well as the pursuit of disjointed initiatives that jeopardized the integration project. The top-down approach employed by the AfCFTA in comparison requires that all member states to the agreement conform to homogeneous standards and priorities in a concurrent manner (Magwape 2018). It has been put forward that by pursuing a top-down approach to integration that builds on the progress already achieved by the RECs, the AfCFTA will succeed in harmonizing and fast-tracking trade facilitation reforms (Magwape 2018). The agreement will, however, need the support of strong institutions that can formulate and coordinate cohesive reform initiatives.

The legal text of the AfCFTA suggests that the agreement seeks to do more than simply align trade facilitation reforms with the commitments of African states to international agreement on this subject matter. The Protocol on Trade Facilitation of the AfCFTA sets a framework enabling technical and financial cooperation between member states towards trade facilitation reform; however, only time will tell how far the agreement is able to cater to the high financial and technical costs associated with the upgrading of trade-enabling systems infrastructure and human resource upskilling.

\subsection{Policy interventions}

The trade facilitation issues that have arisen due to, or been exacerbated by, the COVID-19 crisis suggest that it is essential for the AfCFTA to make strong commitments to policy interventions that reduce the cost of trade on the continent. These could include improving transparency in bureaucratic processes, streamlining border procedures, fostering greater intergovernmental cooperation and communication, and offering greater investor protections. In the immediate term, it is particularly important to keep regional supply chains viable, especially for the provision of critical and essential goods.

\section{Institution of functional national trade facilitation committees}

The various case studies and examples employed to depict the challenges of conducting trade on the continent during the pandemic have made clear the need for not only intergovernmental 
cooperation, but also inter-departmental coordination both nationally and regionally. The issues highlighted are not only customs-related, but have included trade and transport ministries, port and road authorities, freight forwarders, and border agencies. The drafters of both the TFA (WTO n.d.-b) and the AfCFTA (African Union 2018) have shown an awareness of the multi-stakeholder issues surrounding trade facilitation and have thus mandated the creation of national trade facilitation committees (NTFCs). These committees are envisaged to act as 'a consultative mechanism to promote facilitation, examine international trade and transport regulations, make policy recommendations, prepare recommendations and regulations and foster administrative transparency on major trade and transport issues' (World Bank n.d.).

As of June 2020, about 28 African countries had established an NTFC, with an additional two countries reporting to have 'a de facto NTFC' (WTO n.d.-c). Although this is a significant achievement, the mere formation of the committees is insufficient. Real difficulties are faced in making sure these bodies are in actual operation and, more importantly, coordinate with each other. Well-functioning NTFCs could have minimized the losses faced by traders that realized that their goods would be turned back after reaching the border of a neighbouring country, or minimized long border delays as a result of policy uncertainty about the permissibility of the passage of goods. The already-established NTFCs had an opportunity during the COVID-19 pandemic to play a more instrumental role in information dissemination and policy recommendations. The SADC instead opted to coordinate policy through ad-hoc meetings of the SADC cluster of ministers of trade and transport, while the East Africa Community convened an ad-hoc Regional Coordination Committee. The use of NTFCs would have allowed for coordinated and complementary multi-stakeholder engagement in unlocking the challenges faced in the movement of goods during national lockdowns. What happened instead was that individual stakeholders lobbied their respective governments separately for assistance.

For example, the CGA, which represents growers in Zimbabwe and eSwatini, channelled its concerns mainly through the Department of Trade, Industry and Competition (Van Marle 2020). This highlighted that some of the delays they faced were within the scope of the mandate of the DALRRD, others concerned port management, and some were to do with operational changes by freight companies (Van Marle 2020). It can be assumed that such cross-cutting challenges were not specific to the CGA alone and that a multi-stakeholder committee such as an NTFC would have been better positioned to streamline communications between the government and the private sector.

The main policy proposal of this paper is that the AfCFTA Secretariat prioritizes the establishment of NFTCs across member states and, more importantly, that these bodies are placed under close monitoring through regular reporting to assess their work. While the AfCFTA provides for the creation of NTFCs, it is silent on how these bodies should be set up, work, or be evaluated. Article 28 of the Protocol on Trade Facilitation simply reads: 'Each State Party shall establish and/or maintain a National Committee on Trade Facilitation or designate an existing mechanism to facilitate both domestic coordination and implementation of the provisions of this Annex' (AfCFTA, Annex 4, Article 28). The Secretariat has an opportunity to set guidelines on the composition and operation of these committees to maximize their functionality.

Aspects of successful NTFCs globally have been characterized by the WTO (2016) as:

- strong funding that is not reliant on donor funds;

- a firm political commitment to be independent from the government of the day;

- a robust legal basis;

- strong organizational setups; and 
- inclusive composition, particularly to bridge the private-public divide, employing knowledgeable and skilled personal.

Turning to the specific policy matters that the AfCFTA Secretariat can prioritize during and in the aftermath of the global health crisis, inter-border agency cooperation emerges as a frontrunner. Fostering inter-border agency cooperation is difficult, mainly because border agencies maintain their own particular institutional, legal, and procedural frameworks. They do, however, share common interests such as revenue collection, ensuring compliance with trade rules, and defending national security. The policy areas needing the most inter-border cooperation are not new and are even reflected in Article 25 of Annex 4 of the AfCFTA. These include:

- alignment of working hours;

- alignment of procedures and formalities;

- joint controls; and

- establishing one-stop border post controls.

\section{The digitalization of information and documentation transfers}

Digitalization is an ally of trade facilitation, and technological progress is a key driver of international trade. Stakeholders must, however, be prepared to adopt technological and associated changes. Article 17 of Annex 4 recognizes the importance of information technology, stating: 'each State Party shall, to the extent practicable, use the most modern information and communications technology to expedite procedures for the release of goods, including those in transit'. Abandoning the paper-based systems that plague the continent and adopting the use of blockchain technologies, for example, would assist in increasing the transparency of border processes, reduce the margin for human error and corruption by reducing human interfacing, and streamline the time-consuming nature of border clearance (Okazaki 2018). 'Blockchain refers to a type of data structure that identifies and tracks transactions digitally and shares this information across a distributed network of computers, thus creating a sort of distributed trust network' (Okazaki 2018). The AfCFTA Secretariat can offer assistance towards this system overhaul by providing capacity building for the upskilling of border agency personnel. The Secretariat may also facilitate stakeholder buy-in into the system through information dissemination on the benefits of digitalizing border processes. Although the initial investment cost to digitalize the system can be expected to be high, it is commonly calculated that the returns in trade efficiency will be quickly realized (Okazaki 2018).

\section{Promoting investment in port infrastructure}

Ports are vital in the supply chain in Africa, with each port having a far-reaching trade importance, often spanning a number of countries. Ports have thus become a natural focus for regional development. There is a strong imperative for Africa and for African states to invest in ports. Turning back to the African regionalization agenda, it is recommended that states focus on developing port infrastructure ahead of demand, and focus on the ports with the greatest volume potential with the aim of positioning African ports as attractive destinations for global trade ( $\mathrm{PwC}$ 2018). Increased trade volumes and more productive and attractive ports will accelerate changes in global shipping routes serving Africa.

Improving the ways ports are run and managed, for example by creating greater capacity and reducing delays for shippers, is key to making ports more efficient. These interventions have been proposed to reduce the overall cost of logistics and to improve the reliability of goods in transit (PwC 2018). Across the continent, there has been a general lag in port investment, with expansion 
and expenditure on port assets often not keeping pace with trade growth (PwC 2018). Cumulatively, these challenges stifle economic growth by increasing logistics costs and reducing reliability, which together increase the cost of intra-African trade. Another challenge for African ports is that shipment sizes are small compared to those globally, driving up the unit cost of a shipment. This means moving a single container (or any other unit of volume) from Africa is 1.53.5 times more expensive than for high-volume trade routes over a comparable distance ( $\mathrm{PwC}$ 2018).

Smart ports have been proposed as a leading solution to the challenges most commonly faced by ports. 'A smart port is one that uses automation and new technologies such as artificial intelligence, big data, internet of things and block chain to improve its performance' (Walker and Reva 2020). Automation has been posed as critical for enhancing the competitiveness and efficiency of a port, with programmed equipment handling day-to-day operations. Examples include cranes, selfdriving trucks, and pallet sensors. Big data enables new planning guides and facilitates port logistics through the collection and correlation of information on ship positions as they arrive at or leave the port (Chelin and Reva 2020). Through the internet of things, ports can be transformed into maritime information-network hubs (Chelin and Reva 2020).

The pandemic has heightened the need for greater investment in African ports; however, any such investment would be best served if underlined by the streamlining of intergovernmental clearance processes, traffic management in and around the ports, and greater collaboration between the public and private sectors, particularly in the area of defence against cyber threats. The AfCFTA has the opportunity to foster intergovernmental cooperation in these areas, as well as to foster an environment conducive to investment in infrastructure by, for example, strengthening and harmonizing investment regimes and strengthening the rule of law and governance on the continent through greater monitoring.

\section{Conclusion}

Enhancement of trade facilitation is one of the foundational pillars of the African regional integration project. The trade-related challenges being faced at many border posts on the continent are a result of a lack of clear communication channels between interstate agencies and industries, a lack of policy cohesion at the national level, and a lack of hard and soft trade facilitation infrastructure. The challenges at the seaports are indicative of more longstanding structural deficiencies that have been heightened by the health crisis. These challenges are particularly disconcerting within the context of a global health crisis, as the efficient transportation of essential goods is critical for curbing the spread of the virus. Beyond the pandemic, the efficient transportation of goods will ensure maximum benefits from trade integration. The pandemic has highlighted areas through which the AfCFTA may foster greater interstate cooperation by depicting the grave and avoidable consequences of interregional policy incoherency for a continent so heavily reliant on the free movement of goods across borders.

Learning from the deficiencies of the global trading system exposed by COVID-19, Africa needs to explore legal and policy tools that would enable the AfCFTA to facilitate the least hindered flow of trade in essential products at times of difficulty such as this. From this perspective, African countries should build on the momentum triggered by COVID-19 to introduce new interim rules to fast-track trade facilitation measures within the continent while accelerating the implementation of the AfCFTA and its trade facilitation rules. 
The primary policy recommendations made by this working paper centre around the institution of functional NTFCs within the foundational framework of the AfCFTA. Although the focus of this paper has been on the hard infrastructure that supports more trade facilitation, that is not to suggest that the impact of soft infrastructure is to be undermined. Large investments in the hard infrastructure alone will not necessarily lead to lower trade costs. Complementary steps in regulatory reform will lead to the most significant impact on reducing the cost of interregional trade particularly (Portugal-Perez and Wilson 2012).

The NTFCs are envisaged to act as 'a consultative mechanism to promote facilitation, examine international trade and transport regulations, make policy recommendations, prepare recommendations and regulations and foster administrative transparency on major trade and transport issues'. To date, although 28 of these committees can be found across the continent, they appear to exist only in law, without operational capacity.

In response to the COVID-19 health crisis, African RECs have developed regional trade facilitation protocols that have been spearheaded primarily by the SADC cluster of ministers of trade and transport. This approach has predominantly sidelined the direct inputs of the private sector and other governmental authorities, thereby resulting in delays in the resolution of technical trade blockages. The experience of the CGA best exemplifies this issue.

Other policy proposals included the digitalization of document and information transfer between traders and border agencies. Blockchain technologies have been proposed as a viable data structure that would allow all transit border and other government agencies to gain access to and verify all clearance paperwork before the shipment arrives. This would increase the transparency of border clearance processes, as such documentation would be available to all stakeholders simultaneously; it would also improve the efficiency of the system by facilitating pre-clearance processes.

Finally, in light of the strategic importance of efficient ports, the paper makes the proposal for the Secretariat to prioritize and facilitate the digitalization of African ports.

Through these policy proposals, this research highlights the need for further research in three key areas. First, an in-depth case study of the existing NTFCs, so as to better understand what institutional support the AfCFTA Secretariat may offer in establishing and strengthening these committees. Second, further research into the digitalization of border agencies is necessary, particularly through blockchain technologies, to ascertain the nature of the technical and financial commitment states would have for such a digitalization project. Finally, it would be worthwhile to conduct a regional study of possible avenues of cooperation between sub-Saharan African ports, to spread both the costs and the benefits of port renovations.

\section{References}

Africa CDC (2020). 'Outbreak Brief 31: Coronavirus Disease 2019 (COVID-19) Pandemic'. Addis Ababa: Africa Centres for Disease Control and Prevention. Available at: https://africacdc.org/download/outbreak-brief-31-covid-19-pandemic-18-august-2020 (accessed 23 August 2020).

African Union (2012). 'Boosting Intra-African Trade'. 18th Ordinary Session of the African Union Heads of State, January 2012. Available at: https://au.int/en/ti/biat/about (accessed 23 August 2020).

African Union (2018). 'Agreement Establishing the African Continental Free Trade Agreement'. Signed in Kigali 21 March 2018. Available at: 
https://au.int/sites/default/files/treaties/36437-treaty-consolidated_text_on_cfta_-_en.pdf (accessed 15 July 2020).

Brenton, P., and V. Chemutai (2020). 'Trade Responses to the COVID-19 Crisis in Africa'. Policy Note. Washington, DC: World Bank. https:/ / doi.org/10.1596/33548

Chelin, R., and C. Reva (2020). 'Security vs Efficiency: Smart Ports in a Post-COVID-19 Era'. ISS Today, 26 May. Available at: https://issafrica.org/iss-today/security-vs-efficiency-smart-ports-in-a-postcovid-19-era (accessed 7 April 2021).

Chidede, T. (2018). 'World Trade Organization Trade Facilitation Agreement: An African Perspective'. tralacBlog, 18 November. Stellenbosch: Tralac Trade Law Centre. Available at: www.tralac.org/blog/article/13680-wto-trade-facilitation-agreement-an-african-perspective.html (accessed 7 April 2021).

Chidede, T. (2020). 'Temporary Suspension of Import Tariffs on Medical Products and Equipment Essential Amid the COVID-19 Pandemic in Africa'. tralacBlog, 7 April. Stellenbosch: Tralac Trade Law Centre. Available at: www.tralac.org/blog/article/14492-temporary-suspension-of-importtariffs-on-medical-products-and-equipment-essential-amid-the-covid-19-pandemic-in-africa.html (accessed 23 August 2020).

Chiguvare, B. (2020). '15km Queue at Beitbridge Border Between Zimbabwe and South Africa'. SA People News, 29 July. Available at:

www.sapeople.com/2020/07/29/15km-queue-at-beitbridge-border-between-zimbabwe-and-southafrica (accessed 8 September 2020).

Erasmus, G. (2018). 'How Will the AfCFTA Co-Exist with Other African Trade Arrangements?' Stellenbosch: Tralac Trade Law Centre. Available at: www.tralac.org/discussions/article/12868-howwill-the-afcfta-co-exist-with-other-african-trade-arrangements.html (accessed 24 August 2020).

FreshPlaza (2020). 'South Africa's Ports Remain Open, but at Reduced Levels', 27 March. Available at: www.freshplaza.com/article/9203468/south-africa-s-ports-remain-open-but-at-reduced-levels (accessed 23 August 2020).

Gronholt-Pedersen, J. (2020). 'From Bikes to Blockchain: Shipping Industry Goes Digital in Lockdown'. Hellenic Shipping News Worldwide, 29 May. Available at: www.hellenicshippingnews.com/from-bikes-toblockchain-shipping-industry-goes-digital-in-lockdown (accessed 23 August 2020).

The Herald (2020). 'Controls Hit Cross Border Traders', 24 March. Available at: www.herald.co.zw/controlshit-cross-border-traders (accessed 8 September 2020).

ITC (2017). Charting a Roadmap to Regional Integration with the WTO Trade Facilitation Agreement. Geneva: International Trade Centre.

Jansen, M., M. Jallab, and M. Smeets (eds) (2014). Connecting to Global Markets: Challenges and OpportunitiesCase Studies Presented by WTO Chair-Holders. Geneva: World Trade Organization. https://doi.org/10.30875/52979795-en

Lowitt, S. (2019). 'Decreasing Import Customs Fraud in the Context of Customs Modernisation Trends'. Research Report. Pretoria: Trade \& Industrial Policy Strategies. Available at: www.tips.org.za/research-archive/trade-and-industry/item/3721-decreasing-import-customs-fraudin-the-context-of-customs-modernisation (accessed 23 August 2020).

Magwape, M. (2018). 'The AfCFTA and Trade Facilitation: Re-arranging Continental Economic Integration'. Research Paper. Pretoria: University of Pretoria.

Maromo, J. (2020). 'We Will Never Close Beitbridge Border, Says Home Affairs Minister Aaron Motsoaledi'. IOL, 16 March. Available at: www.iol.co.za/news/south-africa/limpopo/we-will-neverclose-beitbridge-border-says-home-affairs-minister-aaron-motsoaledi-44985263 (accessed 8 September 2020).

Meintjes, F. (2020). 'PPECB Proves Its Worth'. Eurofruit, 27 March 2020. Available at: www.fruitnet.com/eurofruit/article/181309/ppecb-proves-its-worth (accessed 23 August 2020). 
Moïsé, E., and S. Sorescu (2013). 'Trade Facilitation Indicators: The Potential Impact of Trade Facilitation on Developing Countries' Trade'. OECD Trade Policy Papers 144. Paris: OECD Publishing. https://doi.org/10.1787/5k4bw6kg6ws2-en

Muleya, T. (2020). 'Consolidate Cargo Piles Up at Beitbridge Border Post'. The Chronicle, 7 September. Available at: www.chronicle.co.zw/consolidate-cargo-piles-up-at-beitbridge-border-post (accessed 8 September 2020).

Mwangi, N. (2020). 'Zambia Reopens Border with Tanzania to Cargo After COVID-19 Closure'. CGTN Africa, 15 May. Available at: https://africa.cgtn.com/2020/05/15/zambia-reopens-border-withtanzania-to-cargo-after-covid-19-closure (accessed 7 November 2020).

Okazaki, Y. (2018). 'Unveiling the Potential of Blockchain for Customs'. WCO Research Paper 45. Brussels: World Customs Organization.

Oulmane, N., M. Jallab, and P.R. Zidouemba (2020). 'The African Continental Free Trade Area and Measures to Facilitate Trade Could Significantly Mitigate COVID-19's Economic Impact in Africa'. Africa In Focus, 22 May 2020. Available at: www.brookings.edu/blog/africa-infocus $/ 2020 / 05 / 22 /$ the-african-continental-free-trade-area-and-measures-to-facilitate-trade-couldsignificantly-mitigate-covid-19s-economic-impact-in-africa (accessed 7 April 2021).

Portugal-Perez, A., and J.S. Wilson (2012). 'Export Performance and Trade Facilitation Reform: Hard and Soft Infrastructure'. World Development, 40(7): 1295-1307.

https://doi.org/10.1016/j.worlddev.2011.12.002

PwC (2018). 'Strengthening Africa's Gateways to Trade'. PwC Capital Projects and Infrastructure. London: PwC.

SADC (2020). 'Guidelines on Harmonisation and Facilitation of Cross Border Transport Operations Across the Region During the COVID-19 Pandemic'. Gaborone: SADC.

SARS (n.d.) 'Latest on the Impact of COVID-19 on SARS'. Available at: www.sars.gov.za/Media/Pages/CoronaVirus.aspx (accessed 23 August 2020).

Sela, S., A. Yang, and M. Zawacki (2020). 'Trade Facilitation Best Practices Implemented in Response to the COVID-19 Pandemic'. World Bank Policy Note. Washington, DC: World Bank. https://doi.org/10.1596/33633

South African Government News Agency (2020). 'Mbalula Details Transport Interventions Amid COVID19', 19 March. Available at: www.sanews.gov.za/south-africa/mbalula-details-transportinterventions-amid-covid-19 (accessed 7 November 2020).

TFA4Africa (2021) 'TFA4Africa: Making the WTO Trade Facilitation Agreement Work for Africa'. Available at: www.tfa4africa.com (accessed 7 April 2021).

Truter, C. (2020). 'COVID-19: Impact on Businesses and Investments in South Africa'. Bowmans, 8 April. Available at: www.bowmanslaw.com/insights/mergers-and-acquisitions/covid-19-impact-onbusinesses-and-investments-in-south-africa (accessed 23 August 2020).

Tshuma, E. (2020). 'Coronavirus and Freight Forwarding in SADC'. tralacBlog, 9 April 2020. Stellenbosch: Tralac Trade Law Centre. Available at: www.tralac.org/blog/article/14502-coronavirus-and-freightforwarding-in-sadc.html (accessed 23 august 2020).

Tuomisto, V. (2018). 'Regional Integration Through Joint Trade Facilitation Reforms'. International Trade Forum (ITC), 20 December. Available at: www.tradeforum.org/news/Regional-integration-throughjoint-trade-facilitation-reforms (accessed 23 August 2020).

Van Marle, G. (2020). 'South African Exporters Face Problems as Peak Season Looms'. The LoadStar, 13 May. Available at: https://theloadstar.com/south-african-citrus-exporters-facing-problems-as-peakseason-looms (accessed 7 November 2020).

Viljoen, W. (2019). 'Trade Facilitation Challenges in Southern Africa'. tralac Trade Brief. Available at: www.tralac.org/publications/article/14218-trade-facilitation-challenges-in-southern-africa.html (accessed 23 august 2020). 
Walker, T., and D. Reva (2020). 'Tech Innovations are Key to South Africa's Maritime Security'. ISS Today, 14 September. Available at: https://issafrica.org/iss-today/tech-innovations-are-key-to-southafricas-maritime-security (accessed 7 November 2020).

WorldAware (2020). 'COVID-19 Alert: Border Crossing Delays Between Zimbabwe \& South Africa Reported August 4 Due to Health Screenings', 4 August. Available at: www.worldaware.com/covid19-alert-border-crossing-delays-between-zimbabwe-south-africa-reported-aug-4-due-health (accessed 7 April 2021).

World Bank (n.d.). 'Connectivity, Logistics \& Trade Facilitation: Facilitating Trade at the Border, Behind the Border, and Beyond'. Available at: www.worldbank.org/en/topic/trade-facilitation-and-logistics (accessed 24 August 2020).

WTO (2016). 'Trade Facilitation Agreement. National Committees on Trade Facilitation: Current Practices and Challenges'. Available at:

https://www.tfafacility.org/sites/default/files/news/tfa_national_committees_trade_facilitation_w eb (accessed 7 November 2020)

WTO (n.d.-a). 'COVID-19: Measures Affecting Trade in Goods'. Available at: www.wto.org/english/tratop_e/covid19_e/trade_related_goods_measure_e.htm (accessed 23 August 2020).

WTO (n.d.-b). 'Agreement on Trade Facilitation: Article 8'. Available at: www.wto.org/english/docs_e/legal_e/tfa-nov14_e.htm\#art8 (accessed 15 July 2020).

WTO (n.d.-c). Trade Facilitation Agreement Database. Available at: https://tfadatabase.org/ratifications/over-time (accessed 7 November 2020). 